\title{
THE EFFECT OF PLACEMENT AND WORK CLIMATE ON EMPLOYEE WORK PRODUCTIVITY IN NATIONAL EDUCATION AUTHORITIES EAST OKU DISTRICT
}

\author{
Helisia Margahana ${ }^{a *}$ \\ ${ }^{a)}$ Sekolah Tinggi Ilmu Ekonomi Trisna Negara, Ogan Komering Ulu Timur, Indonesia \\ ${ }^{*}$ Corresponding Author: helisiagaraika87@gmail.com
}

Article history: received 20 August 2019; revised 31 August 2019; accepted 16 September 2019

\begin{abstract}
This study aims to analyze partially and jointly the effect of placement, work climate on employee productivity and to analyze the most dominant variables in influencing the work productivity of employees at the East OKU District National Education Office, the results of regression analysis and the correlation between job placement and work climate. employees show a regression model. The results showed that joint placement $\left(\mathrm{X}_{1}\right)$ and work climate $\left(\mathrm{X}_{2}\right)$ had a significant effect on work productivity $(\mathrm{Y})$, but had a more dominant effect on the work climate, namely $\hat{Y}=5.309+0.683 \mathrm{X}_{1}+0.292 \mathrm{X}_{2}+\mathrm{e}$ with a coefficient of 0.911 at $95 \%$ confidence level, found that placement and climate can simultaneously predict employee productivity. For the East OKU Regency National Education Office, in building employee work organizations, organizations that play an important role, employees who need a conducive and comfortable climate. Organizational climate can be measured by the sense of responsibility that everyone has, as well as how work standards and job expectations are generated. Employees need rewards for recognition of their work. Efforts to increase employee productivity, leaders must place employees according to their educational background with their field of work, increase employee productivity, listen to employee suggestions and opinions, provide motivation, are reliable and involve the role of employees so that employees can show better performance.
\end{abstract}

Keywords: placement; work climate; productivity

\section{INTRODUCTION}

In an institution, human resources have a very important role in the management of other resources. Because the role of human resources in the institution is very important, these resources must receive good management from the company. This management includes recruitment, selection, placement, and others. Recruitment, selection, and placement activities have an important role in the success of a company, because these activities can demonstrate the ability of the company and organization to survive, adapt and develop in the midst of intense competition [1].

The success of an organization is largely determined by the quality of the people who work in it. The changing environment that is so fast demands their ability to capture the phenomenon of change, analyze its impact on the organization and prepare steps to deal with these conditions [2]. The suitability of employees' work placements with educational backgrounds is one of the factors that affect employee productivity. Siswanto [3] 2007 states that the placement of workers is a process of assigning tasks and jobs to workers who have passed the selection process to carry out continuity with the authority and responsibility with a determined portion and composition and being able to account for all the risks and risks [4]. possibilities that occur in their functions and jobs. that authority and responsibility. The implementation of employee placement must also pay attention to the principle of efficiency, namely the suitability of the skills required by employees. Work placement and motivation, in improving the performance of an employee, are also influenced by a conducive organizational climate. A condition that can cause feelings of pleasure and quality in a person [5]. Employees with high job loyalty will find it easier to cooperate with the company, so that employees are able to work in accordance with existing standards in the company. Employee job loyalty grows when the organizational climate in the company is positive so that it can provide a feeling of security [6].

There are several factors that need to be considered in the placement of employees, namely, academic achievement factors (education level), experience factors (skills), physical and mental health factors, attitude factors, situational factors, motivational factors and opportunity factors. as a conducive working climate. Namely conditions that can cause feelings of pleasure and quality in a person. The work climate is one of the factors that is quite influential on one's job satisfaction. The influence of the work climate will be felt by the employees and will be very decisive in achieving the goals expected [7]. Every effort to improve services is also followed by efforts to improve service quality. The low quality of service is influenced work skills and work climate [8].

A good working climate for employees can have a positive impact and progress for the organization. A conducive work climate will create a sense of belonging for all working employees. Therefore, they will work sincerely without coercion. If the work is done sincerely and without a sense of compulsion, of course, it will have a positive impact and progress for the organization or company where they work [9]. An increase or decrease in employee motivation is directly proportional to an increase or decrease in employee productivity. So that if the level of employee work discipline is high, the employee's work productivity will also be high. Conversely, if the level of employee work motivation is low, 
the work productivity of the employee is also low [10]. Perception scale of work environment conditions. This scale is a modification of several research scales compiled. Trianasari [11](2005) measurements are made by looking at indicators in physical and non-physical aspects, these indicators are work facilities, cooperation in work groups (togetherness), communication, pressure and work responsibilities, air circulation and temperature, structure \& job descriptions, freedom of decision making, lighting, sound control, and cleanliness of Triana [11] workplace. Attitude plays a big role in human life, because if an attitude has been formed in the human self then that attitude will follow to determine how to behave towards the objects around it [12]

The East OKU Regency National Education Office is an element that administers government affairs in the education sector led by the Head of the Service who is under and responsible to the Regent through the Regional Secretary, who requires human resources who can carry out their duties properly in carrying out their duties. government system, especially in its implementation. In the implementation of regional autonomy, it is necessary to support the readiness of outstanding employees. Humans as social beings need unlimited things, this is also influenced by a conducive organizational work climate. A condition that can cause feelings of pleasure and quality in a person. Good work is very important to exist in an organization, with a good working climate it is hoped that employees will work hard and are eager to achieve high work productivity. In addition to work placement in increasing employee work productivity.

\section{RESEARCH METHODS}

In general, this study aims to examine the effect of the placement and work climate in the East Oku Regency National Education Office and the existing variables are applied to the placement and work climate of employees, in this case employee productivity.

Specifically, this study aims to see: The influence between the placement and work climate of employees in the East Oku Regency National Education Office with the work productivity of employees. The method used in this research is a survey method with a correlational approach. The research variables consisted of the independent variables, namely the placement (X1) and the working climate (X2) with the variables namely Employee Productivity (Y).

To obtain data in the field, a questionnaire was prepared based on the indicators on the research variables. The primary data needed is data regarding the placement (X1) and work climate of employees with the dependent variable, namely Employee Productivity at the National Education Office of East Oku Regency.

\section{RESULTS AND DISCUSSION}

Based on the results of this test, it shows that there is a positive relationship between placement and work climate with the work productivity of employees at the East Oku Regency National Education Office, the functional relationship formed between the independent and variable variables indicates that employee work productivity is the result of the placement and work climate variables.

This is indicated by the coefficient value of 0.911 which is stated to be very significant. The contribution of placement and work climate to the work productivity of employees in the East Oku Regency National Education Office is $95 \%$ which is stated by the coefficient of determination. The partial coefficient of Principal Supervisor (with controlled emotional intelligence variable) is 0.720 which is stated to be very significant. $\hat{\mathrm{Y}}=74.46+0.53 \mathrm{X} 1$

Based on the simple linear regression equation $\hat{\mathrm{Y}}=$ $5.309+0.683 \mathrm{X} 1+0.292 \mathrm{X} 2+\mathrm{e}$, it is estimated that each increase in the work placement score will increase the employee work productivity score increase of 0.683 at a constant of 72.00 and each increase in the score The work climate will increase the employee work productivity score of 0.292 at constant 76.50 The results of this study conclude that the placement and work climate that is owned provides a positive contribution which has a significant effect on Job Satisfaction.

This is in accordance with the theory put forward by B. Siswanto Sastrohadiwiryo [13] argues that the aim of holding employee placement activities is "to place employees as elements of work executing in positions that match their abilities, skills and expertise". Furthermore, B. Siswanto Sastrohadiwiryo [13] argues that: placing the right workforce in the right position is not only the company's dream, but also the worker's desire. That way, the supervising workforce can find out the scope of work allocated to them so that those who are confused can see the scope of work. The beneficial effect of the company is the enthusiasm for work and the discipline of work related work.

Thus the findings of facts and data in the analysis of this study further support previous findings regarding a strong relationship between placement and work climate on work productivity, either directly or indirectly. Based on the results of the research and discussion above, it can be indicated that one of the efforts to increase the work productivity of employees at the East Oku Regency National Education Office is to increase or develop employee placement and work climate. Based on the results of the research above, it can be ignored that the placement and work climate provide a positive contribution which has a significant effect on employee work productivity at the National Education Office of East Oku Regency.

\section{CONCLUSION}

The results showed that joint placement (X1) and work climate (X2) had a significant effect on work productivity $(\mathrm{Y})$, but had a more dominant effect on the work climate, namely $\hat{\mathrm{Y}}=5.309+0.683 \mathrm{X} 1+0.292 \mathrm{X} 2+\mathrm{e}$ with a coefficient of 0.911 at $95 \%$ confidence level, found that placement and climate can simultaneously predict employee productivity. For the East OKU Regency National Education Office, in building employee work organizations, organizations that play an important role, employees who 
need a conducive and comfortable climate. Organizational climate can be measured by the sense of responsibility that everyone has, as well as how work standards and job expectations are generated. Employees need rewards for recognition of their work. Efforts to increase employee productivity, leaders must place employees according to their educational background with their field of work, increase employee productivity, listen to employee suggestions and opinions, provide motivation, are reliable and involve the role of employees so that employees can show better performance.

In an effort to increase employee productivity, leaders should be able to place employees according to their educational background with their field of work, supervise employee work productivity, listen to employee suggestions and opinions, provide motivation, interact and involve employee roles so that employees can show performance even better.

\section{REFERENCES}

[1] Wulandari, Winarningsih. 2016. Pengaruh Rekrutmen, Seleksi, dan Penempatan Karyawan Terhadap Kinerja Karyawan. Jurnal Ilmu dan Riset Manajemen. Volume 5, Nomor 4

[2] Charles L. Salindeho, 2016. Analisis Pengaruh Iklim Kerja Dan Pengembangan Karir Terhadap Komitmen Karir Dengan Kepuasan Kerja Sebagai Variabel Intervening. Jurnal Riset Bisnis dan Manajemen Vol 4 ,No.3, Edisi Khusus SDM 2016: 303-318

[3] Siswanto. 2007. Pengantar Manajemen. Jakarta, Indonesia: Bumi Aksara

[4] Sedarmayanti. 2001. Sumber Daya Manusia dan Produktivitas Kerja. Bandung: Mandar Maju.

[5] Emelda, Penempatan Kerja Dan Motivasi Serta Iklim Organisasi Dalam Mempengaruhi Kinerja Karyawan PT. Sucofindo (Persero) Wilayah Sumatera SelatanBangka Belitung. Jemasi Vol.14 No.2, Jul-Des 2018

[6] Heni Mar'atusholihah. 2010. Hubungan Antara Loyalitas Kerja Karyawan Dengan Iklim Organisasi Positif. Yogyakarta: Fakultas Ilmu Sosial dan Humaniora Universitas Islam Negeri Sunan Kalijaga Yogyakarta

[7] Aluguro, K. S. 2004. Analisis Pengaruh Iklim Kerja Terhadap Kepuasan Kerja Pegawai di Sekretariat Daerah Kota Semarang. Program Studi Magister Manajemen Universitas Diponegoro Semarang.

[8] Pramono, A. 2004. Analisis Keterampilan Kerja dan Iklim Kerja terhadap Kualitas Pelayanan Keperawatan di Ruang Rawat Inap RSU H.Sahudin Kutacane. Medan: Tesis, Program Pasca Sarjana Universitas Sumatera Utara.

[9] Suwatno. 2003. Manajemen Sumber Daya Manusia. Jakarta: Erlangga.

[10] Ridwan Purnama, Pengaruh Motivasi Kerja Terhadap Produktivitas Kerja Karyawan Pada
Bagian Produksi CV. Epsilon Bandung. Jurnal Strategic, Volume 7, Nomor 14, September 2008

[11] Trianasari, Y. 2005. Hubungan Antara Persepsi Terhadap Insentif dan Lingkungan Kerja dengan Loyalitas Kerja. Surakarta: Fakultas Psikologi Universitas Muhammadiyah Surakarta.

[12] Y. Suchyadi, Relationship between Work Motivation and Organizational Culture in Enhancing Professional Attitudes of Pakuan University Lecturers," J. Humanit. Soc. Stud., vol. 01, no. 01, pp. 41-45, 2017.

[13] Siswanto-Sastrohadiwiryo, B, 2002. Mana-jemen Tenaga Kerja Indonesia: Pendekatan Administratif dan Operasional.fakarta: Bumi Aksara. 